\title{
TINJAUAN PERILAKU KEJAHATAN BERDASARKAN PERSPEKTIF TIGA DIMENSI KEPRIBADIAN P-E-N DALAM TEORI ANALISIS FAKTOR HANS J. EYSENCK
}

\author{
Bambang Setiawan \\ IAIN Syekh Nurjati Cirebon \\ Email: setiawan89.bambang@gmail.com
}

\begin{abstract}
Abstrak
Berdasarkan sudut pandang teori kepribadian analisis faktor Hans J. Eysenck, mengemukakan penjelasan yang kontroversial mengenai penyebab perilaku kejahatan yang dapat dipengaruhi oleh faktor kepribadian. Tinjauan empiris mengenai konsep yang dikemukakan Eysenck tentang perilaku kejahatan memunculkan beragam dukungan. Para tokoh menyetujui bahwa psychoticism yang tinggi memiliki kecenderungan berhubungan dengan perilaku kejahatan, neuroticism lebih tinggi pada kelompok kriminal daripada populasi normal, serta extraversion-introversion berkaitan dengan under-socialized. Metode penelitian yang digunakan yaitu library research untuk mengkaji mengenai perilaku kejatahatan ditinjau berdasarkan sudut pandang tiga dimensi kepribadian Psychoticism, Extraversion-Introversion, dan Neuroticism dalam teori analisis faktor Hans J. Eysenck. Ditemukan hasil bahwa, konsep mengenai korelasi antara tiga dimensi kepribadian Eysenck, yaitu Psychoticism, Extraversion-Introversion, dan Neuroticism terhadap perilaku kejahatan atau kriminalitas memiliki korelasi yang signifikan.
\end{abstract}

Kata Kunci : Perilaku Kejahatan, Psychoticism, Extraversion-Introversion, Neuroticism, Analisis Faktor.

\section{PENDAhuluan}

Keragaman individu merupakan faktor esensial dalam mengungkap bagaimana perbedaan setiap individu terhadap perilaku yang ditampilkannya. Faktor-faktor dalam perbedaan individu ini seperti, kepribadian, inteligensi, ingatan; ataupun faktor fisik seperti ukuran badan, tinggi badan, jenis kelamin, usia, dan faktor lainnya yang dapat diteliti dan dapat digunakan dalam memahami keragaman individu.
Eysenck (1966) merupakan salah satu tokoh yang paling berpengaruh dalam bidang differential psychologists. Analisis faktor digunakan untuk mengidentifikasi sifat-sifat yang membentuk kepribadian seseorang. Pengklasifikasian perilaku merupakan hal yang sangat esensial sebagai tahapan awal untuk mengukur perilaku manusia, dan analisis faktor merupakan alat atau cara terbaik dalam mengklasifikasikan perilaku manusia. 
Analisis faktor mengkritisi penelitian yang menekankan atas dasar teori, untuk mengangkat hal esensial dari teknik penelitian terhadap teori. Analisis faktor mengkritisi penggambaran kepribadian hanya secara rata-rata, dan gambaran umum (abstraksi) saja.

Teori analisis faktor yang dikeluarkan oleh Hans J. Eysenck dikenal dengan gigantic three, yaitu sebuah konsep yang merujuk kepada tiga faktor utama dari dimensi kepribadian, yaitu Psychoticism (P), Extraversion-Introversion (E), dan Neuroticism (N), yang kemudian disebut dengan PEN. Ketiga dimensi kepribadian ini bersifat orthogonal, dimana saling berdiri sendiri dan tidak berkorelasi satu sama lain, sehingga skor tinggi dari salah satu faktor tidak berpengaruh terhadap skor dari faktor lainnya. Dalam pandangan teori ini, tidak ada faktor lain selain PEN yang dibutuhkan untuk mengungkap kepribadian seseorang.

Teori analisis faktor Eysenck menekankan pada dasar biologis dari kepribadian manusia, perilaku yang ditampilkan manusia merupakan refleksi dari perilaku dasar otak. Salah satu bagian otak yang berperan penting sebagai variabel antara kepribadian manusia dengan perilaku-perilaku yang dihasilkannya adalah cortical arousal. Ketiga faktor kepribadian PEN dihubungkan oleh arousal untuk menghasilkan perilaku atau sifat yang akan ditampilkan oleh masing-masing tipe kepribadian tersebut.

Eysenck mengemukakan bahwa kepribadian merupakan jumlah total dari tingkah laku aktual atau potensial yang berpola pada organisme, ditentukan oleh hereditas dan lingkungan. Kepribadian berasal dan terbentuk melalui interaksi fungsional empat sektor utama dimana pola-pola tingkah laku ini diorganisasikan, yaitu sektor kognitif (intelegensi), sektor konatif (karakter), sektor afektif (tempramen), dan sektor somatik (konstitusi) (Hall \& Lindzey, 1985).

Fakta bahwa manusia merupakan organisme biologis dan produk dari lingkungan sosial, pengaruh faktor biologis dan faktor sosial secara konstan berinteraksi satu sama lain (Eysenck, 1976). Eysenck mempostulasikan bahwa manusia berbeda karena hereditas, dalam hal bagaimana otak dan sistem saraf pusat bereaksi terhadap lingkungan dan memproses rangsangan dari lingkungan, dan perbedaan ini berhubungan terhadap dimensi kepribadian (Hall \& Lindzey, 1985).

Teori Eysenck menekankan pada dasar biologis dari kepribadian manusia. Kepribadian tidak hanya pada perilaku yang nampak, yang dapat dimanipulasi atau diubah, tetapi juga merupakan refleksi dari perilaku dasar otak. Eysenck mendalilkan bahwa perbedaan cortical arousal bertanggung jawab terhadap perbedaan domain kepribadian (Kar, 2013). Proses biologis atau genetika menghasilkan perubahan perilaku yang jelas menunjukkan bahwa terdapat hubungan sebab-akibat yang memiliki dua fungsi.

Seperti yang diketahui, Eysenck melihat kepribadian dipengaruhi oleh faktor lingkungan dan hereditas 
(keturunan). Hal ini sesuai dengan yang diungkapkan oleh Boeree (1998) bahwa Eysenck menekankan kebiasaan yang dipelajari sebagai alasan utama perbedaan dalam kepribadian, akan tetapi, Eysenck juga menunjukkan hal tersebut pada konfigurasi genetik pada individu. Sehingga perbedaan kepribadian pada setiap individu bisa disebabkan atau dipengaruhi oleh faktor belajar dari lingkungan, ataupun berasal dari faktor gen yang diwariskan dari generasi sebelumnya pada individu.

Analisis faktor merupakan alat yang esensial dalam teori trait-factor analytic, merupakan prosedur statistika yang didasarkan atas konsep korelasi, analisis faktor memberikan arah atau cara yang sederhana dalam menjelaskan sejumlah besar nomor variabel dengan mengidentifikasi sejumlah kecil nomor dimensi (faktor-faktor) (Cloninger, 2004). Konsep korelasi yang biasa digunakan dalam analisis faktor adalah, 1) correlation coefficient, yaitu pengukuran terhadap hubungan dua variabel (dua set nomor), korelasi positif jika variabel tinggi berhubungan dengan variabel tinggi lainnya dan variabel rendah berhubungan dengan variabel rendah lainnya, serta nilai koefisien korelasinya berada pada rentang -1 dan +1 ; dan 2) correlation matrix, yaitu korelasi dari keseluruhan pasangan variabel dengan menggunakan pengkomputerisasian (Cloninger, 2004).

Dalam analisis faktor digunakan metode ilmiah, analisis faktor merupakan satu dari sekian banyak metode untuk mengukur penggunaan konsep khusus terhadap tipe-tipe material khusus, terutama untuk permasalahan psikologis (Eysenck, 1976). Para psikolog telah satu langkah lebih maju daripada para ahli statistik dalam hal penggunaan analisis faktor. Lebih lanjut Eysenck (1976) menjelaskan bahwa para ahli statistik secara keseluruhan lebih memperhatikan terhadap pendeskripsian nilai yang dihasilkan dari metode ini, berbeda dengan para psikolog, dimana telah jauh mempertimbangkan mengenai pemaknaan dari faktor-faktor yang dihasilkan.

Analisis faktor merupakan metode paling efektif dibandingkan dengan metode statistika lainnya, hal ini karena analisis faktor dapat berinteraksi sangat dekat dengan aspek-aspek substantif (sebenarnya) dari penelitian psikologis (Eysenck, 1976). Dapat disimpulkan bahwa analisis faktor dapat memberikan pemahaman secara detail dan mendalam, serta memberikan pemaknaan terhadap faktor-faktor yang dihasilkan, hal ini karena analisis faktor mengidentifikasi secara mendalam dan dapat menghasilkan hasil yang sesuai dengan kondisi sebenarnya.

Eysenck (Feist \& Feist, 2006) mengemukakan empat kriteria dalam mengidentifikasi factors, yaitu 1) psychometric evidence, adanya faktor harus mapan atau tetap, kriteria yang dianggap wajar harus reliable dan replicable; 2) possess heritability, faktor berikutnya harus memiliki faktor keturunan dan sesuai dengan model genetik; 3) make sense from a theoretical view, Eysenck menggunakan metode deduktif dalam melakukan investigasi, di awali dengan teori dan kemudian mengumplkan data 
yang logis dan konsisten dengan teori; dan 4) possess social relevance, harus dibuktikan dengan perhitungan matematis bahwa faktor-faktor mendapatkan hubungan dengan variabel yang relevan secara sosial.

\section{METODE PENELITIAN}

Pendekatan yang digunakan dalam penelitian ini adalah pendekatan kualitatif, dengan menggunakan metode penelitian kepustakaan. Penelitian kepustakaan merupakan kegiatan penelitian yang dilakukan secara sistematis untuk mengumpulkan, mengolah, dan menyimpulkan informasi dan data dengan bantuan berbagai macam material yang tersedia, seperti buku, hasil penelitian terdahulu, artikel, serta jurnal ilmiah terkait guna mencari jawaban atas permasalahan yang dihadapi (Khatibah, 2011; Sari \& Asmendri, 2020). Penelitian ini menggunakan pendekatan metaetnografi, yaitu merangkum berbagai hasil penelitian yang relevan secara naratif untuk mengembangkan teori baru dan melengkapi teori-teori sebelumnya (Yusuf \& Yusuf, 2020).

\section{HASIL DAN PEMBAHASAN}

Penelitian oleh Levine \& Jackson (2004) terhadap 101 mahasiswa yang berusia 22 tahun, untuk mengukur kepribadian dalam tiga dimensi PEN dengan perilaku kejahatan dan undersocialized. Hasil yang diperoleh menunjukkan bahwa dimensi kepribadian PEN secara signifikan dapat memprediksi perilaku kejahatan secara lebih sistematis. Psychoticism secara signifikan memiliki korelasi dan dapat memprediksi perilaku kejahatan dan under-socialized, yaitu perilaku yang tidak cukup berasimilasi dengan masyarakat atau antisosial. Hasil yang diperoleh Levine \& Jackson (2004) mendukung hipotesis bahwa psychoticism merupakan indikator yang kuat dari aktivitas sosial yang tidak tepat atau maladaptif, dan sesuai dengan hasil studi sebelumnya bahwa tidak menghormati aturan berhubungan dengan kurangnya tanggung jawab sosial, yang merupakan tanggung jawab terhadap saling berhubungannya psychoticism dengan delinquency (Farrington et al., 1982; Furnham \& Thompson, 1991; Blackburn, 1999).

Neuroticism secara signifikan memiliki korelasi dan dapat memprediksi under-socialized. Secara parsial mendukung alasan teori kriminalitas Eysenck dan konsisten dengan pengetahuan mengenai hubungan antara neuroticism dengan kejahatan (Farrington et al., 1982; Furnham \& Thompson, 1991; Blackburn, 1999). Extraversion merupakan dimensi kepribadian yang memiliki tingkat reliabilitas dan hubungan paling sedikit dengan perilaku kejahatan (Eysenck \& Eysenck, 1992; Levine \& Jackson, 2004). Menurut pandangan Eysenck \& Eysenck (1970) bahwa kemampuan sosial memiliki hubungan yang sangat rendah dengan perilaku kejahatan.

Eysenck sangat berhati-hati dalam menyebutkan bahwa tidak ada seorang pun yang murni dalam hal apapun, individu yang neurotic tidak selalu neurotic sepanjang waktu, masingmasing indivudu merefleksikan 
kombinasi tertentu dari ketiga dimensi ini dan banyak subdimensi lainnya (Hall \& Lindzey, 1985). Eysenck mengungkapkan tiga dimensi utama dari kepribadian manusia, yaitu psychoticism, extraversionintroversion, dan neuroticism (Hall \& Lindzey, 1985; Boeree, 1998; Feist \& Feist, 2006).

\section{A.Psychoticism}

Individu yang memiliki psychoticism bukan berarti individu tersebut orang gila (psychotic) atau menuju kearah sana. Individu yang memiliki psychoticism yang tinggi ditunjukkan dengan sikap-sikap, seperti sembrono, bersikap acuh tak acuh, dan menunjukkan eksperi emosi yang tidak tepat/tidak pantas. Dimensi kepribadian ini memisahkan individu dari institusi masyarakat (Boeree, 1998).

\section{B. Extraversion-Introversion}

Eysenck (dalam Boeree, 1998) berhipotesis bahwa extraversionintroversion merupakan persoalan keseimbangan dari "inhibition" dengan "excitation" di dalam otak manusia. Excitation ialah otak dalam keadaan "up", yang menjadikan individu menjadi lebih waspada. Inhibition ialah otak dalam keadaan "down", biasanya akan menimbulkan perasaan rileks, dan juga rasa untuk melindungi diri. Individu yang extravert memiliki inhibition yang kuat, sedangkan individu yang introvert memiliki inhibition yang lemah.

Sebagai contoh perbedaan respon dari individu yang extravert dengan introvert ketika mengalami keadaan trauma akibat kecelakaan mobil. Individu yang extravert meskipun mengalami pingsan akibat kecelakaan tersebut langsung berani untuk menanyakan kejadian yang telah menimpanya, mental impact dari kecelakaan tersebut tidak dirasakan oleh individu yang extravert, dan bahkan sudah siap untuk mengendarai mobil lagi. Berbeda dengan individu yang introvert, trauma yang disebabkan oleh kecelakaan tersebut akan menyebabkan lebih waspada, dan akan menyebabkan individu tersebut enggan untuk kembali mengendarai mobil atau butuh waktu yang cukup lama untuk bisa mengendarai mobil lagi.

\section{Neuroticism}

Neuroticism merupakan nama yang diberikan oleh Eysenck bagi individu dalam rentang normal, cukup normal, sampai dengan individu dengan keadaan "nervous" atau gelisah, gugup, dan takut. Penelitian yang dilakukan Eysenck (dalam Boeree, 1998) menunjukkan bahwa individu yang mengalami nervous termasuk kedalam nervous disorder atau neuroses. Akan tetapi, Eysenck tidak berkata bahwa individu dengan skor neuroticism yang tinggi tidak semata-mata individu tersebut menderita neurotics, individu tersebut diduga hanya mengalami masalah neurotics.

Hipotesis Eysenck (dalam Boeree, 1998) bahwa beberapa individu memiliki sympathetic nervous system yang lebih responsif daripada individu lainnya. Sympathetic nervous system merupakan bagian dari nervous 
system yang berfungsi secara terpisah dari central nervous system dan mengendalikan respon emosi manusia ketika dalam keadaan/situasi berbahaya. Beberapa individu akan tetap tenang meskipun dalam situasi bahaya, namun beberapa individu akan merasakan ketakutan atau lebih emosional ketika dalam situasi bahaya, ataupun bahkan beberapa individu lebih ketakutan meskipun hanya dalam situasi bahaya yang bersifat minor.

Konsep extraversion-introversion memiliki sejarah yang panjang dalam psikologi, kembali ke masa lalu ke masa Hippocrates dan Galen (Eysenck, 1987). Awalnya teori mengenai empat tipe kepribadian, yakni melancholic, choleric, phlegmatic, dan sanguine dipertahankan, diuraikan secara rinci, dan diletakkan sebagai pusat dari psikologi Eropa oleh Kant sekitar 300 tahun yang lalu (1912-1918). Wundt (dalam Eysenck, 1987) merupakan orang pertama yang mengambil empat kategori kepribadian ini dan diturunkan menjadi dua dimensi independen. Tipe choleric dan sanguine mendasari extraverted, kemudian tipe melancholic dan phlegmatic merupakan rangkaian yang mendasari introverted, yang mana tipe melancholic dan choleric mendasari ketidakstabilan (level $\mathrm{N}$ atau Neuroticism tinggi), serta tipe phlegmatic dan sanguine mendasari kestabilan (level $\mathrm{N}$ atau Neuroticism rendah) (Eysenck, 1964; Eysenck, 1987).

Pertama kali yang menampilkan pandangan mengenai arousal sebagai faktor penyebab dalam perilaku extraverted dan introverted adalah seorang psikiatris Austria Otto Gross (1902; 1909), yang memperkenalkan konsep fungsi "primary" dan "secondary" (Eysenck, 1987). Konsep ini merupakan dasar psikologis dan merujuk pada aktivitas sel otak selama produksi berbagai bentuk konten mental, yang mengantarkan pada nervous processes yang dilibatkan dalam produksi tersebut. Nervous processes menggantikan arousal sebagai gagasan dalam pikiran yang diharapkan akan kuat, meskipun bukan pada level sadar, dan menentukkan pembentukan asosiasi dalam pikiran (Eysenck, 1987).

Teori kepribadian Eysenck berfokus pada sifat-sifat dari extraversion-introversion, neuroticism, dan psychoticism, dimana multiple arousal systems sebagai pusat konstruknya (Matthews \& Gilliland, 1999). Eysenck memiliki asumsi bahwa sifat-sifat kepribadian individu berbedabeda sesuai dengan fungsi otaknya masing-masing, fungsi otak ini lah berisi "kunci" yang relevan terhadap kepribadian dan perilaku seseorang. Eysenck (dalam Matthews \& Gilliland, 1999) mengidentifikasi dua fungsi utama dari sistem otak sebagai komponen kunci dalam konsep nervous system, yaitu reticulo-cortical circuits dan reticulo-limbic circuits. Reticulocortical circuits mengendalikan cortical arousal yang dihasilkan oleh stimulus yang baru masuk, sedangkan reticulolimbic circuits mengendalikan respon dari stimulus emosional. 
Matthews \& Gilliland (1999) mengungkapkan bahwa extraversionintroversion (E) berkaitan terhadap arousability dari reticulo-cortical circuits. Analisis secara metodologi terhadap studi extraversion oleh Gale (1973) (dalam Matthews \& Gilliland, 1999) menjelaskan dua dasar masalah utama. Pertama, individu dengan aktif menggapai level arousal, sehingga hubungan antara kepribadian dengan arousal bisa juga merefleksikan perbedaan individu dalam strategi untuk mencari atau menghindar terhadap pendorong atau stimulus.

Kedua, dibawah level tinggi dari stimulus, sebagai pencegah "transmarginal inhibition" (TMI) yang menuntun secara bertentangan dalam menurunkan level arousal. Eysenck (1994) berpendapat bahwa "...in the case of the most arousing testing conditions we might suspect that the optimal point for introverts, but not for extraverts, had already been passed, so that extraverts' arousal was still growing, introverts' declining". Oleh karena itu, introverts bisa jadi lebih tinggi, lebih rendah ataupun sama level arousal-nya dengan extraverts, berdasarkan kepada interaksi yang kompleks dari tipe-tipe kepribadian dan manipulasi lingkungan.

Neuroticism (N) berhubungan dengan arousability dari limbic circuit, neurotic lebih menjadi penggugah daripada penstabil individu sebagai konsekuensi dari pengaruh stimulus emosi. Oleh karena itu, perbedaan individu dalam Neuroticism hanya pada konteks emosional dan stress (Matthews \& Gilliland, 1999). Salah satu kekuatan teori Eysenck ialah penggunaan arousal sebagai variabel penghubung yang mengizinkan kepribadian secara kualitatif untuk terhubung dengan berbagai daftar respon yang berbeda-beda.

Individu yang memiliki dimensi Normality-Extraversion memiliki kecenderungan untuk lincah dan cepat tanggap; Normality-Introversion dapat diandalkan dan bijaksana; NeuroticismExtraversion mudah tersinggung dan agresif; sedangkan orang yang Neuroticism-Introversion cemas dan pesimis. Dimensi utama yang ke-3, yang diusulkan oleh Eysenck adalah Normality-Psychoticism. Harus digaris bawahi bahwa psychoticism $(\mathrm{P})$ tidaklah sama dengan psychosis, seperti schizophrenia, meskipun orang yang schizophrenic akan memiliki skor yang tinggi dalam psychoticism. Orang yang memiliki $\mathrm{P}$ yang tinggi cenderung untuk bermusuhan/berseteru dan dianggap aneh oleh orang lain (Hall \& Lindzey, 1985).

Secara umum, Eysenck menemukan bahwa extraversion berkorelasi dengan kecenderungan untuk tidak terkondisi dengan mudah, sementara introversion siap dan mudah terkondisi, perbedaan ini dipengaruhi oleh level cortical excitation. Menurut Eysenck pada extraversion, level cortical excitation secara umum rendah, individu seperti ini cenderung untuk mencari stimulus dan butuh lebih banyak stimulus untuk merangsangnya dibanding orang lain butuhkan; sedangkan pada introversion, level excitation tinggi, individu introversion cenderung untuk menghindari stimulus tambahan dan hanya dibutuhkan sedikit 
stimulus untuk merangsangnya (Hall \& Lindzey, 1985).

Ketika seseorang memiliki emosional reaktif yang tinggi (neurotic pada dimensi normality-neuroticism) dan memiliki cortically excitable yang tinggi (introvert pada dimensi introversion-extraversion),

kemungkinan individu tersebut akan mengalami gejala neurotic yang kuat seperti ketakutan, fobia, compulsif, obsesi, dan lain sebagainya. Individu seperti ini akan menderita disorder tipe 1, seperti anxiety neurotic (kecemasan neurotik) (Hall \& Lindzey, 1985).

Individu yang memiliki kereaktifan emosi yang tinggi tetapi memiliki level cortical excitation yang rendah (ekstravert pada dimensi introversionextraversion) menderita disorder tipe ke-2, seperti psikopat atau kepribadian antisosial (Hall \& Lindzey, 1985). Individu yang menunjukkan tingkah laku antisosial, seperti kenakalan atau kriminalitas, tidak memperoleh reaksi ketakutan yang kuat (atau rasa bersalah) terhadap impuls yang merusak mereka. Hal ini seperti yang ditunjukkan dalam Tabel 1 berikut.

Tabel 1. Introversion-Extraversion, Neuroticism \& Physiological Arousal Cortical Level of Excitation Automatic Level Nervous System Reactivity

\section{INTROVERT}

\begin{tabular}{|c|c|c|c|}
\hline Normal & & High & Low \\
\hline $\begin{array}{l}\text { Neurotic } \\
\text { anxiety } \\
\text { neurotic) }\end{array}$ & (e.g., & High & High \\
\hline
\end{tabular}

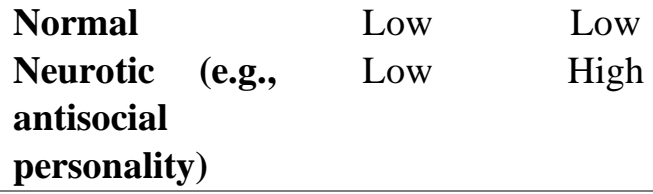

Identifikasi terhadap dasar fisiologis dimensi psychoticism (P) menjadi lebih spekulatif, Eysenck menyimpulkan berdasarkan studi genetik tingkah laku dari heritabilitas psychoticism, dimensi ini memiliki dasar biologis yang kuat sebagaimana kedua dimensi lainnya, pandangan Eysenck didasarkan pada hubungan fisiologis berdasarkan fakta bahwa pria memiliki skor psychoticism (P) yang lebih tinggi dari wanita, hal ini mungkin terjadi karena hormon seks pria mempengaruhi dalam beberapa bagian, mesipun tidak sepenuhnya terhadap dasar psychoticism (Hall \& Lindzey, 1985).

Neuroticism dan psychoticism tidak hanya terbatas pada individu yang mengalami patologis, meskipun orang yang terganggu cenderung untuk mendapatkan skor yang tinggi dibanding orang normal dalam skala pengukuran kedua faktor ini (Feist \& Feist, 2006). Pernyataan ini sesuai dengan yang diungkapkan oleh Hall \& Lindzey (1985) bahwa psychoticism (P) tidaklah sama dengan psychosis seperti contohnya schizophrenia, meskipun orang yang schizophrenic akan memiliki skor yang tinggi dalam psychoticism. Cloninger (2004) pun sependapat bahwa meskipun istilah psychoticism terkesan melebih-lebihkan image patologi, pada kenyataannya orang-orang yang kreatif cenderung memiliki skor pyshoticism yang tinggi, meski pasien psychotic memiliki skor 
yang tinggi dalam faktor ini, tapi begitu juga halnya dengan orang-orang kreatif yang tidak menderita kelainan ini.

Eysenck menerima model diathesisstress bagi orang yang memiliki skala neuroticism tinggi, yaitu bahwa stress dan skor $\mathrm{N}$ (neuroticism) yang tinggi bergabung akan meningkatkan kerentanan seseorang terhadap kelainan psikologis. Model ini juga mengusulkan bahwa orang yang memiliki skor psychoticism tinggi dan mengalami stress memiliki kesempatan tinggi dalam membentuk kelainan psychotic. Model diathesis-stress ini mengusulkan bahwa orang-orang dengan skor $\mathrm{P}$ tinggi secara genetik lebih rentan terhadap stress dibanding dengan yang memiliki skor P rendah. Selama masamasa stress yang rendah, orang-orang dengan skor $\mathrm{P}$ tinggi mungkin dapat berfungsi secara normal, akan tetapi ketika psychoticism tinggi mengalami level stress tinggi, orang tersebut menjadi rentan terhadap psychotic disorders, sedangkan orang dengan skor $\mathrm{P}$ rendah tidak rentan terhadap stress dan akan melawan psychotic meskipun mengalami stress yang berat (Feist \& Feist, 2006).

Berdasarkan sudut pandang teori kepribadian analisis faktor, Eysenck mengemukakan penjelasan yang kontroversial mengenai penyebab tindak kejahatan berdasarkan kaca mata kerpibadian, bahwa faktor kepribadian merupakan penyebab utama perilaku kejahatan dan hanya metode sistematis yang dapat digunakan untuk menginvestigasinya (Eysenck, 1996; Eysenck \& Gudjonsson, 1991; Levine \& Jackson, 2004).
Kepribadian memiliki proximal (seperti kognisi) dan kemudian distal consequences (seperti perilaku sosial, salah satunya yaitu kejahatan) (Levine \& Jackson, 2004). Hal ini berdasarkan pada Eysenck (1996; 1997) bahwa perilaku kejahatan dijelaskan dalam paradigma kepribadian secara umum, paradigma ini mengusulkan bahwa distal antecedents (genetic personality determinants atau faktor penentu kepribadian berdasarkan gen), dan proximal antecedents (faktor biologis) penyebab dari psychometric trait constellations (seperti Psychoticism, Extraversion, dan Neuroticism).

Dasar rasional mengenai pengaruh kepribadian terhadap perilaku kejahatan diperkuat dengan pernyataan berikut. Extraversion disebabkan oleh tingkat paling bawah dari cortical arousal, dimana menghasilkan kebutuhan untuk meningkatkan stimulus dan pengkondisian (classical conditioning) yang lemah, kemudian Eysenck (1996) menegaskan bahwa introvert lebih terpengaruh oleh hukuman (punishment), dimana penghargaan (reward) lebih berpengaruh terhadap extravert (Levine \& Jackson, 2004). Fakta-fakta terbaru, mengusulkan bahwa tingkat tinggi kemampuan sosial dari extravert merupakan hasil kepekaan penghargaan dimana ini merupakan ciri-ciri inti dari extraversion (Lucas et al., 2000).

Berdasarkan konseptualisasi Eysenck, neuroticism memiliki dasar biologis di dalam autonomic nervous system, meskipun fakta-fakta terbaru membantah pandangan ini (seperti Fahrenberg, 1988). Secara ilmu perilaku, tindakan neuroticism sebagai 
arahan alami yang memperkuat kecenderungan perilaku dengan kebiasaan. Dalam istilah kejahatan, neuroticism yang tinggi membuat individu lebih keras hati dan gigih sehingga kejahatan diperkuat menjadi sebuah rutinitas. Sebaliknya, melihat pada aturan sosial seperti kemampuan belajar di sekolah, neuroticism yang tinggi mengganggu keefisiensian proses belajar. Pasangan antara extraversion yang tinggi dan neuroticism yang tinggi menghasilkan ketidakmampuan mengendalikan keadaannya dan meningkatkan kemungkinan perilaku kejahatan (Levine \& Jackson, 2004).

Psychoticism bisa saja berhubungan dengan perilaku kejahatan yang membuat individu keras kepala (toughminded) dan mengurangi kepekaan untuk merasa bersalah (Levine \& Jackson, 2004). Berdasarkan alasan ini, Eysenck (1996) mengemukakan bahwa extraversion, neuroticism dan psychoticism yang tinggi kemungkinan besar menyebabkan kejahatan dan aktivitas kriminal.

Tinjauan empiris mengenai status dari teori kejahatan atau kriminalitas yang dikemukakan oleh Eysenck (1996) memunculkan beragam dukungan (Blackburn, 1999; Farrington et al., 1982; Furnham \& Thompson, 1991). Para tokoh di atas menyetujui bahwa psychoticism yang tinggi hampir selalu berhubungan dengan aktivitas kejahatan; neuroticism lebih tinggi dalam kelompok kriminal daripada populasi normal; dan extraversion secara umum lebih tinggi ketika metode self-report digunakan pada populasi umum, tetapi tidak dalam sampel kriminal.

Pekerjaan Eysenck dalam mengungkap skala utama dari faktorfaktor kepribadian yang lebih berkaitan sebagai peramal (predictors) dari perilaku kejahatan (Eysenck \& Eysenck, 1970). Extraversion, skala utamanya adalah kemampuan sosial menjadi bagian unsur utama dari faktor E, tetapi bisa saja sedikit kurang berkaitan daripada impulsiveness, atau resiko yang di ambil dari perilaku kejahatan atau sensasi kejahatan yang dicari (Eysenck \& Eysenck, 1970). Inventori kepribadian yang dirancang oleh Eysenck \& Eysenck (1971) untuk menggambarkan $\mathrm{P}$ (Psychoticism), E (Extraversion), dan $\mathrm{N}$ (Neuroticism), telah menuntuk pada kesimpulan bahwa impulsiveness bertanggung terhadap korelasi antara kejahatan (kriminalitas) dan extraversion (tetapi bukan kemampuan sosialnya) (Levine \& Jackson, 2004).

Psychoticism merupakan faktor sumber penjelasan, ciri-ciri (trait) dari psychoticism cukup menyerupai apa yang sering ditunjukan dalam perilaku kejahatan. Eysenck menyimpulkan bahwa item-item psychoticism berhadapan dengan perilaku melukai orang lain dan binatang. Neuroticism, mengungkap analisis bahwa kejahatan merupakan "autonomic type", hal ini merujuk pada manifestasi langsung dari sympathetic arousal atau interpretasi mawas diri dari arousal dalam bentuk perasaan khawatir, perasaan tegang, cemas, dan lain sebagainya (Eysenck \& Eysenck, 1971). 


\section{KESIMPULAN}

Eysenck melihat kepribadian dipengaruhi oleh faktor lingkungan dan faktor hereditas (keturunan), sehingga perbedaan kepribadian individu bisa dipengaruhi oleh faktor belajar dari lingkungan ataupun berasal dari faktor keturunan (gen) yang diwariskan. Selain itu, Eysenck dikenal sebagai pakar yang menekankan kepribadian manusia pada dasar biologis, kepribadian tidak hanya pada perilaku yang nampak yang dapat dimanipulasi, tetapi juga merupakan refleksi dari perilaku dasar otak. Seperti yang dikemukakan oleh Eysenck bahwa tidak ada hal yang mutlak yang dapat berdiri sendiri, seperti halnya dalam dimensi kepribadian Eysenck dimana satu dimensi kepribadian saling terhubung membentuk sifat-sifat seorang individu. Konsep mengenai korelasi antara tiga dimensi kepribadian Eysenck, yaitu Psychoticism, ExtraversionIntroversion, dan Neuroticism terhadap perilaku kejahatan atau kriminalitas memiliki korelasi yang signifikan.

\section{REFERENSI}

Blackburn, R. (1999). The Psychology of Criminal Conduct. New York: Wiley.

Boeree, C. G. (1998). Personality Theories: Hans Eysenck. Psychology Department Shippensburg University.

Cloninger, S. C. (2004). Theories of Personality Understanding Persons Fourth Edition. New Jersey: Pearson Education, Inc.

Eysenck, H. J. (1976). Psychology as a Bio-Social Science. Dalam Eysenck, Hans J. \& Wilson, Glenn D. A Textbook of Human
Psychology (1 ( $^{\text {st }} \quad$ Edition $)$. Lancaster: MTP Press Ltd.

Eysenck, H. J. (1987). Arousal and Personality: The Origins of a Theory. Dalam Eysenck, Hans J. \& Strelau, Jan. Personality Dimensions and Arousal. New York: Springer Science + Business.

Eysenck, H. J. (1994). Personality: Biological Foundations. Dalam P. A. Vernon, The Neuropsychology of Individual Differences. London: Academic Press.

Eysenck, H. J. (1996). Personality and Crime: Where do We Stand? Psychology, Crime and Law, 2, hlm 143-152.

Eysenck, H. J. (1997). Personality and Experimental Psychology: The Unification of Psychology and the Possibility of a Paradigm. Journal of Personality and Social Psychology, 73, hlm. 1224-1237.

Eysenck, H. J., \& Eysenck, M. W. (1992). Personality and Individual Differences. New York: Plenum.

Eysenck, H. J., \& Gudjonsson, G. H. (1991). The Causes and Cures of Criminality. London: Plenum Press.

Eysenck, S. B. G., \& Eysenck, H. J. (1970). Crime and Personality: An Empirical Study of the Three Factor Theory. British Journal of Criminology, 10, hlm. 225-239.

Eysenck, S. B. G., \& Eysenck, H. J. (1971). Crime and Personality: Item Analysis of Questionnaire Responses. British Journal of Criminology, 11, hlm. 49-62. 
Fahrenberg, $\quad$ J. (1988). Levine, S. Z. \& Jackson, C. J. (2004). Psychophysiological Processes. Dalam J. R. Nesselroade \& R. B. Cattel, Handbook of Multivariate Experimental Psychology (hlm. 867-914). New York: Plenum Perss.

Farrinigton, D. P., Biron, L., \& LeBiron, M. (1982). Personality and Delinquency in London and Montreal. Dalam J. Gunn \& D. P. Farrington (Eds.), Abnormal Offenders, Delinquency and the Criminal Justice System (hlm. 153-201). New York: Wiley.

Feist, J., \& Feist, G J. (2006). Theories of Personality. New York: Mc Graw Hill.

Furham, A., \& Thompson, J. (1991). Personality and Self-Reported Delinquency. Personality and Individual Differences, 12, hlm. 585-593.

Hall, C. S. \& Lindzey, Gardner. (1985). Introduction to Theories of Personality. Singapore: John Wiley \& Sons.

Kar, S. (2013). Hans Eysenck: Contributions \& Controversies. Delhi Psychiatry Journal 16 (1) 53-56.

Khatibah, K. (2011). Penelitian Kepustakaan. Iqra': Jurnal Perpustakaan dan Informasi, 5(01), hlm. 36-39. Eysenck's Theory of Crime Revisited Factors or Primary Scales. Legal and Criminological Psychology, 9 (1), 135-152.

Lucas, R. E. et al. (2000). CrossCultural Evidence for the Fundamental Features of Extraversion. Journal of Personality and Social Psychology, 79, hlm. 452-468.

Matthews, G. \& Gilliland, K. (1999). The Personality Theories of $\mathrm{H}$. J. Eysenck and J. A. Gray: a Comparative Review. Personality and Individual Differences Journal 26 583626.

Sari, M. \& Asmendri. (2020). Penelitian Kepustakaan

(Library Research) dalam Penelitian Pendidikan IPA. NATURAL SCIENCE: Jurnal Penelitian Bidang IPA dan Pendidikan IPA, 6(1), hlm. 41-53.

Yusuf, N. M., \& Yusuf, J. M. W. (2020). Faktor-Faktor Yang Mempengaruhi Stres Akademik. Psyche $\quad 165$ Journal, 13(2), 235-239. 